\title{
HEALING CHAINS, RELATIONSHIPS OF POWER AND COMPETING RELIGIOUS IMAGERIES IN THE MONASTERY OF SAINTS KOSMAS AND DAMIAN IN KUKLEN (BULGARIA)
}

\author{
MAGDALENA LUBANSKA \\ Assistant Professor \\ Institute of Ethnology and Cultural Anthropology \\ University of Warsaw \\ Ul. Żurawia 4, 00-503 Warsaw, Poland \\ e-mail: magdalena.lubanska@gmail.com
}

\begin{abstract}
This article* offers an anthropological analysis of a conflict over the use of a set of 'healing chains' and other focal objects kept in the Orthodox Christian monastery of Saints Kosmas and Damian in Kuklen, Bulgaria. In a nutshell, the conflict captures the leading religious imageries propagated by the custodians of the monastery on the one hand, and the spiritual leaders of a new religious movement, so-called Deunovians, on the other. The analysis helps situate some of the significant changes currently affecting the religious culture of Orthodox Christians in Bulgaria within a broader social and cultural context.

KEYWORDS: healing chain • Orthodox Christians $\bullet$ Deunovians $\bullet$ religious imageries $\bullet$ Bulgaria $\bullet$ ekstrasensi
\end{abstract}

\section{N T RODUCTION}

They have a chain there, you may have seen it, in the big church. People place the chain against an ailing body part, the head, a leg, a body part that's in pain, and sleep next to the chain, they have faith and conviction that the problem will go away. ${ }^{1}$ (Parking attendant, Plovdiv, June 25, 2014)

On a warm summer day on June 30, 2013 pilgrims are filing through a narrow door leading from the narthex into the monastery church of SS Kosmas and Damian, in Kuklen. ${ }^{2}$ They buy candles at a stand, and leave prayer requests for their loved ones, living and dead. They light candles in front of the icons, make the sign of the cross, and kiss the icons. Some walk inside to attend a service in the main body of the church. Most venture inside only briefly before heading back to the narthex.

* This work was supported by the National Science Centre in Poland under grant DEC2011/03/D/HS3/01620 titled Anthropological Theories and Social-Religious Life of Orthodox Believers in Local Communities of Eastern and South-Eastern Europe. Working team: Centre for Anthropological Studies on Orthodox Christianity. Article is translated by Piotr Szymczak. 


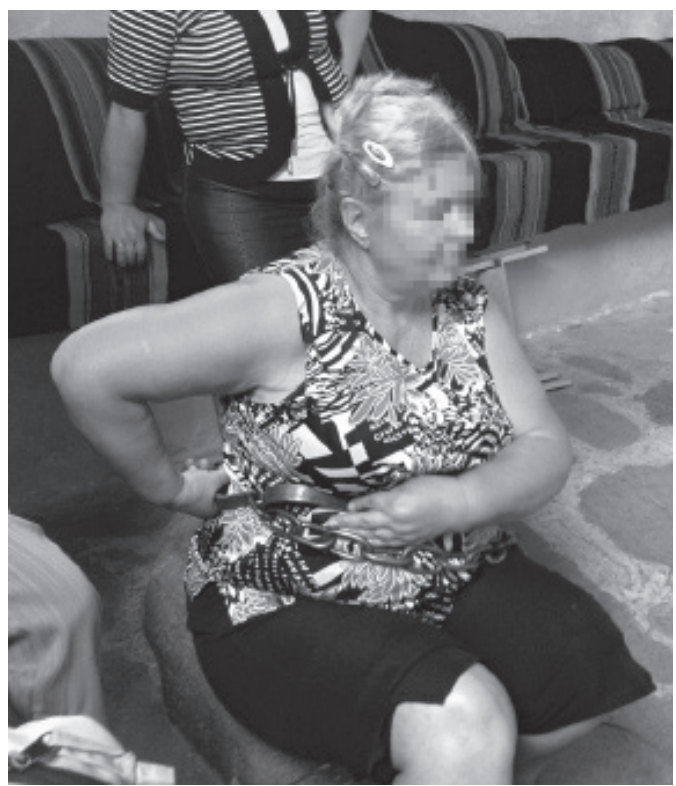

Photo 1. A woman pressing the healing chain against her back in the monastery church of SS Kosmas and Damian, in Kuklen. Photo by Magdalena Lubanska, July 1, 2013.

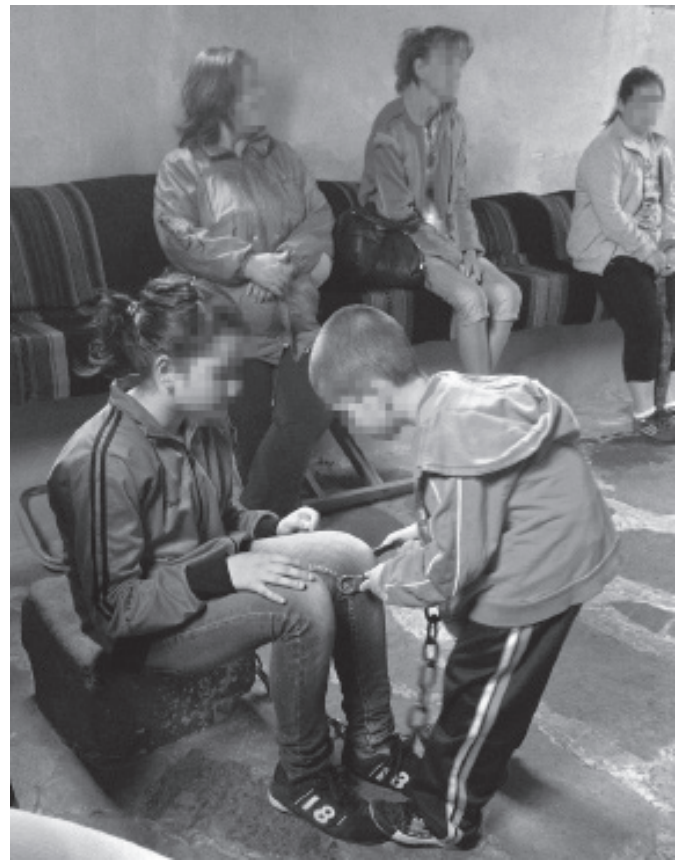

Photo 2. A girl and a boy imitating healing procedures of the grown-ups in the monastery church of SS Kosmas and Damian, in Kuklen. Photo by Magdalena Lubanska, June 30, 2013.
An elderly woman sitting in the south-west corner of the narthex is resting her diseased feet against the links of a chain fastened to a stone. A small line of people is always waiting their turn to sit and rub the chain against their legs and arms, from the bottom upwards. "Could you stop all that clanging while the service is in progress?" the candle seller leans out of her stand at the opposite end of the narthex and snaps at one of the people.

A hush falls on the other people in the narthex. No clinking is heard, the people just sit silently on the stone by the chain for a few moments each. Among them is a young couple with children who are holding balloons their parents bought at a stand by the monastery wall. A woman tells her daughter to sit by the chain for a moment to calm her nerves.

The liturgy over, the pilgrims can now rub the chain against their bodies freely. They start with their arms and legs; some press the chain against other ailing body parts: neck, head or the lower back (Photo 1). Most do so unaided, although some need help. A couple of children, a boy and a girl, go through the ritual they have just learned by imitating grown-ups. The girl is sitting down and the boy is rubbing the chain against her legs (Photo 2). A small percentage of the people do the ritual half-heartedly, as if to say "This might look funny but what's the harm? The chain might actually help." Others perform the ritual with a focused expression, as though it was a standard healing practice that must be executed competently in order to be effective. A woman hangs the chain around her neck, literally chaining herself up. Her face has a calm, pleased expression. I strike up a conversation: apparently, she had been 
healed of depression several years previously, and has now brought a female friend who is likewise in need of healing.

Self-healing practices involving the chain have sparked controversy. There is an evident power struggle going on over the physical and symbolic space of the monastery. It plays out between the chain-focused pilgrims on the one hand, and, on the other, the monastery's current custodians, who regard the practice as being contrary to Christianity or to the spirit of Orthodoxy, and who seek to discourage it in various ways. This article will discuss the nature of that struggle by describing the religious practices and imageries of the pilgrims, their charismatic leaders, and the monastery's current and past custodians as related to the agency and the healing powers of the monastery's set of chains and other sacred objects. The aim is to demonstrate how former custodians of the monastery used to cooperate with believers in the healing practices, and explain the background of the current conflict, stemming from a discrepancy between the religious imageries of the two groups.

\section{THEORETICAL BACKGROUND}

This article analyses religious imageries, by which I mean the beliefs of the pilgrims and the monastery's custodians relating to the monastery's power and status as expressed in a somatic or discursive manner relating to their religious environment. In my approach, beliefs are, on the one hand, the convictions and meanings that devotees attach to ritual practices and, on the other hand, the "embodied epistemology, the sensuous and material routines that produce an integrated (and culturally particular) sense of self, community and cosmos" (Morgan 2010: 8). This case study of a cult of religious objects and of belief in their agency confirms that "belief should be studied as taking place in material practices" (ibid.), and can be understood as that which "holds to a particular habit of feeling, willing, thinking and practise" (ibid.: 6). Hence, not every embodied epistemology has its verbal equivalent, and not everything that matters in a religious sense can be expressed by discursive means. Often, these things play out exclusively on the somatic, bodily level.

Accordingly, I follow Pierre Bourdieu (1977: 72) and Thomas Csordas (2002: 63) in assuming that the "socially informed body" forms the existential basis for the imageries of believers. As such, the body is the principle that generates and unites all practices or, as Maurice Merleau-Ponty (1996 [1945]: 429) put it, "a certain setting in relation to the world". Our perceptions begin in the body, and divisions such as subject/objects or mind/body are secondary to the act of perception:

[...] we do not have any objects prior to perception. To the contrary, our perception ends in objects, which is to say that objects are a secondary product of reflective thinking; on the level of perception we do not have objects, we are simply in the world. (Csordas 2002: 61)

Anthropologists using this theoretical approach aim to identify and describe the mode and manner in which a phenomenon is perceived by social actors, as assimilated and expressed through the body. As Csordas (1994: 8) noted, "phenomenology is a descriptive science of existential beginning, not of already constituted cultural products", 
which constitution depends on intentionality (Csordas 2002: 62). Accordingly, this epistemological perspective invites questions on the kind of social and cultural factors that determine beliefs concerning the efficacy (or otherwise) of certain activities; for instance, whether or not the ritual of rubbing or pressing a chain against a body part will result in healing. This is because the practice expresses a certain specific somatic mode of attention or "culturally elaborated ways of attending to and with one's body in surroundings that include embodied presence of others" (ibid.: 7). In other words, belief is what "I know with my body" (Morgan 2010: 9).

An anthropologist looking at the practices of the pilgrims in the monastery needs to establish how social actors use their bodies for religious socialisation and, inasmuch as is possible, how they talk about such ritual practices. The task is to study the "conditions that shape feelings, senses, spaces, and performances of belief, that is the material coordinates or forms of religious practise" (ibid.: 6).

The term multisensory religious imageries, which I borrow from Csordas, places emphasis on the dual fact that religious socialisation involves all the senses, and that religious practices and imageries are embodied, produced and reproduced by the body: "The locus of the sacred is the body, for the body is the existential ground of culture" (Csordas 2002: 87). Accordingly, it is through the body that social actors objectivise their experience. The body reproduces cultural models and patterns even before the social actor has been able to objectivise, name or realise the same. However, this is not a spontaneous process. So-called "specialists in religious objectification" (ibid.: 65), that is to say people who enjoy trust and command respect in the community, and can therefore orchestrate, discern and classify other people's emotions and reflections, play an important role in objectivising the models or patterns of a given habitus. This may be a matter of social roles (priest, psychologist, teacher, politician, journalist) or individual charisma (religious leaders).

The material presented here demonstrates how such specialists may influence the pilgrims' imageries, and how this corroborates the insight proposed by John Eade and Michael J. Sallnow (1991: 10) (relating to pilgrimage shrines in general):

[...] while apparently emanating an intrinsic religious significance of [their] own, [they] at the same time provide a ritual space for the expression of a diversity of perceptions and meanings with the pilgrims themselves bring to the shrine and impose upon it. As such the cult can contain within itself a plethora of religious discourses.

In described context discourses may be substituted with imageries.

The ethnographic data examined in his article was obtained through fieldwork conducted in the summers of 2013 and 2014. It comprises observations and interviews with pilgrims conducted on the feast of SS Kosmas and Damian (July 1) and on the day before (the eve of the feast), as well as interviews conducted during longer visits to Plovdiv and Kuklen in 2013 and 2014. 
My research in the Kuklen monastery identified two leading models of religious imagery and related specialists in religious objectification. The first is represented by the imagery of the monastery's custodians, namely Bishop Nikolay (the local metropolitan bishop) and the nuns living in the monastery. The second is represented by the imageries of the chain-focused pilgrims orchestrated by local religious leaders: elderly women who propagate esoteric spirituality. In the case under discussion here, this is expressed through the worldview of the Deunovians. ${ }^{3}$

The division draws attention to a conflict within the Bulgarian Orthodox Church, which has been present since the 1990s. ${ }^{4}$ At that point Bulgarian religious life became revitalised, complete with a wave of people returning to the fold of the Orthodox Church; on the other hand, some of the practices engaged in by the devotees were questionable in their orthodoxy. Before that period Orthodoxy was simply taken to comprise the actual religious practices of Orthodox devotees, especially since those were taking place in an adverse political climate. Since the 1990s, some of those practices have come to be increasingly regarded by some hierarchs as being contrary to the spirit of Orthodoxy, where the ideal of Orthodoxy is treated as being synonymous with the Russian Orthodox Church, or, more precisely, an image of that Church tailored to meet the requirements of ideological expediency at any given time..$^{5}$ In that process, new religious movements with an esoteric background, symbolically represented by Baba Vanga (1911-1996) ${ }^{6}$ and Peter Deunov (1864-1944), ${ }^{7}$ appear to function as the 'significant other', against which the Orthodox model moulds the process of religious socialisation of the devotees. Eliminating that influence is difficult: Baba Vanga and Deunov still command considerable respect in Bulgaria, where they are regarded as an element of local colour closely linked to Orthodoxy and endowed with divine gifts.

Importantly, the centuries-old habitus of Bulgarian believers does not favour a strong connection between the people and the clergy; many of the cultural roles associated with priests have long been fulfilled by older female religious leaders (Baeva 2012: 170-171; Marinov 1994: 347). Because Greek clergy predominated in ethnically Bulgarian territories under Ottoman rule (1396-1878), clergymen were not easily accessible in the provinces, and their ties with the local population were loose. Bulgarian clergymen took charge from 1870 onwards following the establishment of an independent Bulgarian Orthodox Church, however those were few in number, and the Church Slavonic language of the liturgy was becoming increasingly incomprehensible to the faithful (Georgieva 2012: 121). Lastly, Bulgarian society after 1944 came under the institutional and ideological influence of the Soviet Union, resulting in increasing rates of atheism and suppression of religious practice through workplace discrimination and persecution. The Bulgarian Orthodox Church held an ambivalent record in that period, especially given its historical indebtedness to the Russian Orthodox Church, to which it owed its independent patriarchate. Although the cultural models embraced in the period of Todor Zhivkov's communist government came from Russia, they were openly hostile to Orthodox Christianity. At the same time some of the Orthodox hierarchs, headed by Patriarch Maxim, collaborated with the atheist state, a fact that some social researchers 
today explain by historical and cultural factors such as the Byzantine tradition of the symphony of powers (cf. Ghodsee 2009).

As correctly noted by Galia Valtchinova (2007: 10):

The decades of collaboration with (and corruption by) the communist regime provoked a deep division within the Bulgarian Orthodox church; from 1992 to 1999, two synods and two patriarchs struggled for the Orthodox souls. This crisis of legitimacy paralysed the Orthodox Church throughout the 1990s, and its aftermath is still perceivable in the beginning of the new millennium.

Currently the Bulgarian clergy continue to face problems including enduring political divisions among Bulgarian hierarchs and even, according to popular opinion, links to organised crime. Also noticeable are certain shortcomings in the way the clergy addresses the expectations of the devotees. I repeatedly witnessed discussions between priests who were unsure if and how they should hold prayers in church settings which, though non-canonical, seemed to be important to the devotees, or whether or not to condone certain doctrinally questionable behaviour ${ }^{8}$ (such as positioning oneself directly under the dome of the church to benefit from the supposed special 'energy' present at that spot).

The controversy affecting the Kuklen monastery as described below is one of the many manifestations of a phenomenon that affects many Bulgarian monasteries and shrines, and which is also noted by researchers working in other Orthodox countries (Russia, Ukraine, Belarus).

\section{The Religious Imagery of the Chain-focused Pilgrims - the "Granny Religious Leaders", the Ekstrasensi ${ }^{9}$ and the Deunovians}

The term "religious imagery of the chain-focused pilgrims" denotes a conglomerate of beliefs and practices prevailing among ordinary believers who visit the monastery, a group that often includes members of the lower clergy (see Rock 2007:3) and focuses on practices targeted at well-being for the "porous self" (Taylor 2007). Such people believe themselves to be permanently vulnerable to harmful powers that can, and need to be averted through protective or reparative rituals. An important role is played by somatic modes of attention aimed at contacts with physical carriers of sacred/beneficent powers. This imagery is embodied rather than expressed discursively. An item's popularity as a focal healing object depends mainly on its record of efficacy corroborated by testimonials of past healings; as a result, religious hierarchs sometimes frown on the believers' enthusiastic cult of such objects, or even on their very use. However, some members of the lower clergy share a fascination with controversial focal healing objects; for instance, the chain-focused religious imagery under discussion here is shared by the monastery's former custodians active in 1998 [2002]-2007, including Father Ivan Shtŭtov, three former monks (Fathers S., ${ }^{10}$ B., and X.), and "Granny A.", a former klisarka, ${ }^{11}$ all of whom regarded their ministrations as a service to the community of the faithful, and did not regard themselves as superior to the chain-focused believers, whose experiences they accepted as credible testimonials of healings.

The religious sensorium of those devotees who represent the chain focused imagery is shaped through somatic, performative practice that produces in the performers a 
sense of psychosomatic satisfaction with their relationship with powerful healing objects. Many devotees are content merely to perform a practice in imitation of others, without seeking cosmological or doctrinal explanations of its meaning. In their case, physical contact alone with an object carrying healing powers is sufficient to produce general wellbeing in the person initiating the practice.

However, the popularity of certain objects believed to be vehicles of healing power is managed or amplified by bioenergy therapists, called ekstrasensi in Bulgaria, in common with the other Orthodox countries. Ekstrasensi often make recommendations to devotees specifying which monasteries they should visit, and what practices they need to undertake in order to be healed of their ailments. They also create discursive commentary on healing objects which may or may not be internalized by the devotees.

Galina Lindquist observed a similar tendency in Russia, where ekstrasensi also frequently refer their clients to specific Orthodox monasteries. However, those ekstrasensi view themselves as forming part of, and acting as spokeswomen for, the Russian Orthodox Church. By way of contrast, Bulgarian healers often regard their methods as an alternative to those of the Church, and are convinced that their own knowledge about the psychosomatic workings of the human organism (including positive and negative energies) is more complete than that of the Orthodox clergy. As Lindquist (2006: 54) explains,

In healing practices the human body is understood [by the ekstrasensi] as being surrounded of some kind of bio-energy field (biopole) organised by 'energo-information structures' that works as programming mechanism and that are connected with the higher source of power through channels. These structures govern the functioning of internal organs, thus determining physical health.

In alternative spirituality this concept of energy is proposed as the causal force or mechanism of the healing processes, however it is not conceptually well-defined in conventional terms. Instead, it comprises a broad variety of spiritual experiences by treating the human body as "a compound energetic node in a holistic network of energy exchange, involved in continuous interplays and processes with all the layers of existence, from the worlds of atoms to the surrounding universe" (Mikaelsson 2013: 170).

In Orthodox countries it is the ekstrasensi who appear to be the chief promoters of this way of looking at the body. The Bulgarian researcher Valtchinova (2007: 19) notes:

The boom of the ES [i.e. ekstrasensi] as a social phenomenon coincided with the political change of 1989-90 and the early postsocialist years [...]; by 1994, more than 440 ES were listed in the official register of the Bulgarian ES healers, published by their Association [...], the majority of them women (72\%). It was the post-communist transition - with its socio-economic crisis, insecurity, and loss of values - that provoked both the search for alternative systems of 'healing' (and the reduction of anxiety, more generally speaking), and an acute hunger for prophecies.

The ekstrasensi promote an inclusive and eclectic spirituality tinged with quasi-scientific terminology, blending Orthodoxy with New Age movements, yoga, Zen and transpersonal psychology (Lindquist 2006: 29-30), as well as ufology, contacts with extra-terrestrial civilisations, astrology, and meditation (Panchenko 2011: 121, 123). There appears to be considerable similarity between those phenomena in Russia and Bulgaria, and the 
latter seems open to cultural influence from Russia concerning this type of spirituality, which forms an increasingly noticeable element of urban culture. Through the ekstrasensi, urban culture in its turn exerts an increasing influence on the imageries relating to monasteries and shrines, and on the pilgrims who visit them.

This phenomenon is clearly noticeable in Plovdiv, a city located seven miles from Kuklen. Plovdiv is the setting of the spiritual activity of D., a female clairvoyant, dowser and bioenergy therapist who plays a significant role in constructing the imageries of the efficacy of religious objects found in the monastery. A gymnast in her youth, D. often used to travel to Russia during the communist period. She completed a programme at the Institute of Non-Traditional Medicine in Moscow, where she took courses in ufology and parapsychology. Her specialism in parapsychology was Man - Earth - Cosmos. She also proudly identified herself as the holder of a diploma from the Bol'shoy Theatre.

I met D. at the Kuklen healing spring (ayazmo). When I approached her she acted as though she had been expecting me, and in a subsequent conversation she explained that her clairvoyant son had told her that on that day she would meet someone by the healing spring who needed her. According to that respondent, children under the age of five or six have supernatural abilities and know more about the world than adults (as a child, her son was allegedly a clairvoyant and spoke in Sanskrit). The woman attaches considerable importance to numerology, phrenology, feng shui, healthy eating, healing properties of water and the existence of 'geopathogenetic zones' or nodal points on the so-called Hartman network. She has practised meditation since childhood, and has occasional prophetic dreams. She believes in reincarnation and individual karma, which she identifies with the divine scheme of things. She claims to have learned much of her self-knowledge from Baba Vanga (whom she once visited), a late Soviet healer named Dzhuna, and another Bulgarian clairvoyant, Vera Kochovska. She claims that sins committed in one life have consequences in the next. She is well known for helping people in difficult situations. She prays for sick people in locations reputed to be places of healing. She also obtains water with particularly potent healing properties by collecting it from several different monasteries (preferably seven) and mixing while reciting incantations over it (zarezhdane).

The former custodians of the monastery used to respect D.'s knowledge and skills, even if, as she puts it, they tended to 'Christianise' her beliefs about the healing power of some of the locations. They helped people together: D. becomes nostalgic when she reminisces about that period in her life. She dreams about becoming a klisarka in the monastery of SS Kosmas and Damian so that she can help people to make 'proper'12 use of the healing agency of the chain. D. claims that SS Kosmas and Damian speak to her directly (she hears their voices); they address her as their sister, and teach her recipes for herbal remedies which she uses to heal people free of charge. The respondent believes that she knows the monastery from her past incarnations; in this life she has been visiting it since the age of four. Her grandmother, who brought her to the monastery as a child, used to say, "Have some of that water, my little one, and every problem will go away". D. remembers how crowds of sufferers used to come to sleep inside the church, especially on the feasts of SS Kosmas and Damian (November 1 and July 1). The monastery matters so much to her that she persuaded a wealthy friend from Belgium to donate a large sum for its restoration. However, she admits that her relations with 
the custodians are strained; she does not visit often or come to the monastery during major holidays, when the noise of the sellers and the crowds drowns out the voices of the saints.

D. is an adherent of Peter Deunov, and always has some of his writings with her. She explains Deunov's teachings to initiates of the White Brotherhood in Plovdiv, and serves as their spiritual guide. Deunovians are a dynamic presence in the area, and they are particularly popular among young educated Bulgarians who treat Orthodox Christianity as a hollow tradition. The Kuklen monastery (or, to be exact, its healing spring or ayazmo and its set of chains) are among the most important healing objects recognised by the Plovdiv adherents of that religious movement.

Echoes of Deunov's teachings also affect older believers who practice 'traditional'13 Orthodox Christianity (what the Bulgarian anthropologist Vihra Baeva [2012] calls the old women's religiosity, in contrast to the religious life of the priests). ${ }^{14}$ Such women are largely unaware that adopting these practices takes them away from institutional Orthodoxy, especially given that they regard Orthodox Christianity as a matter of religious practice rather than some kind of canonical, officially sanctioned variant. For their part the Deunovians not so much reject Orthodox Christianity as they consider their own doctrine to be at a more perfect and advanced stage: a more enlightened and inclusive doctrine offering better chances of spiritual growth and wellbeing.

Deunov's syncretistic, esoteric system reveals strong connections with the theosophy of Helena Blavatsky, neo-pantheism, the esoteric tradition, occult historiography and biologism understood as a form of hygiene, exercise, healthy diet and a lifestyle attuned to natural rhythms, all those things being infused with a religious element (Szwat-Gyłybowa 2011: 91).

This spirituality enjoyed a degree of semi-official sanction from the Bulgarian authorities in the 1970s thanks to the then-minister of culture Lyudmila Zhivkova, daughter of Todor Zhivkov, Bulgaria's long-term head of state and first secretary of the country's communist party. Cut short by her premature death, Zhivkova's public activity focused on developing an esoteric spirituality based on a synthesis of Marxism and occultism (Szwat-Gyłybowa 2006: 333-341). Baba Vanga, a clairvoyant and member of the Bulgarian Communist Party, enjoyed Zhivkova's particular esteem as "she 'worked to build the new socialist paradise', to considerable personal gain. As a medium and a healer, Vanga attracted not only Bulgarians and visitors from neighbouring socialist countries, but also people from the USSR and the West" (Ciesielska 2015). Many respondents I interviewed in my fieldwork in the Rhodope Mountains in 2002-2014 proudly claimed to have personally consulted Baba Vanga for health advice (Lubanska 2015).

This combination of traditional, nominally Orthodox Christian religiosity with esoteric influences from new religious movements has a long tradition in Bulgaria, hibernating in various ideological variants including socialist and neoliberal ones.

New religious movements appear to be growing in popularity in Bulgaria; believers are attracted to various theories of spirituality relying on pseudoscientific terminology. The kind of spirituality they represent is clearly focused on energy, and largely boils down to using it to help others by offering advice and recommendations on energy sources or by reciting correct formulas over an object in order to endow it with positive energy (cf. Lindquist 2006: 29; Kormina 2010: 276). They identify certain locations (for 
example the Seven Rila Lakes) as emanating a power or energy, identified as "cosmic energy" or some other kind of energy related to the location's physical characteristics (cf. Panchenko 2011; 2012; Rock 2012-2013). They argue that the positive physical and spiritual properties of certain items or natural objects stem from their physical properties; for instance, all metals (including metal crosses worn around the neck) screen off negative energy; water flowing through a crystal lattice or a hidden treasure (or containing a submerged metal cross) has healing properties, etc. Sometimes they invoke fanciful pseudo-scientific terminology with an almost empirical air (such as the Hartman network mentioned above). Another favoured rhetorical device consists in invoking their status as continuators of "ancient knowledge" (often rendered implausible by self-defeating anachronisms). Despite these scientific trappings their teachings require a considerable leap of faith.

Orthodox devotees, whose religiosity is often directed at achieving psychosomatic wellbeing, adapt these ideas (often in refracted form), and seek objects reputed to have healing properties, even though they are not always versed in the supposed mechanisms of their efficacy as explained by the ekstrasensi. Often the only reason for visiting the monastery is to approach such life-giving objects as miracle-working icons, relics or (in the case of the Kuklen monastery specifically), a set of healing chains.

Importantly, this need for palpable, sensory contact with the numinous has been validated and cultivated in Orthodox doctrine since the Byzantine period (Talbot 2002). With the obvious exception of the period of iconoclastic controversy, Eastern Christianity has regarded sensory contact with the sacred as being just as valid as verbal contact ever since the Fifth, Sixth and Seventh Councils (cf. Evdokimov 1964: 248; Belting 1996). Why, then, are the custodians of the monastery so troubled by the devotees' sensory interactions with objects found in the monastery? Why are they wary not only of the touching of the set of chains in the church's narthex, but also about the touching of the icons?

\section{The Imagery of the Monastery's Custodians - Metropolitan Bishop Nikolay and Igumenia Anastasiya}

The second model is favoured by the monastery's current custodians, i.e. Igumenia Anastasiya and two other nuns working in the monastery and, more importantly, by the Bishop of Plovdiv. The model involves an unambiguously purist perspective, and takes a suspicious stance with regard to the religious practices of the devotees on account of their "superstitious" (Bulgarian sueverni) ways. In this model, devotees who practice those are viewed as being merely nominal Orthodox Christians whose religious practice is "adulterated" by various un-Orthodox, "pagan" and neopagan elements coming from new religious movements.

The current custodians of the monastery believe that healing can be achieved through prayer, receiving Holy Communion, and using the water from the holy spring, but not by using the chains. To them, believing in the healing power of the chains is tantamount to idolatry, a view expressed by a female candle seller who assists the monastery staff in selling candles on the feast of SS Kosmas and Damian:

In themselves, those chains have no healing power. It's prayer that heals. But many people have this mistaken belief that they will be healed if they touch an affected 
part of their body with the chain. It's not true. It's some kind of superstition. The chains produce no healings; prayers do, the icon of SS Kosmas and Damian does, a worshipper's heartfelt prayer does, provided that the person is religious [...] They used to bring ill people here, and they would bind them to constrain their movements, right? Then the priest would say prayers over them, give them Holy Communion, give them holy water and take them to the ayazmo where they could be bathed in water from the ayazmo. This water is quite cold but it's never given anyone a cold. (Kuklen, June 30, 2013)

The fundamental error attributed to the devotees in this approach is that their practices are focused on materiality, meaning that religious life becomes centred on the agency ${ }^{15}$ of powerful objects. Members of the clergy are made apprehensive by the possibility that devotees might visit churches or monasteries not so much to seek salvation through prayer, but merely in order to utilize their interactions with powerful healing objects (which may or may not be recognised by the Orthodox Church as legitimate channels of divine grace) ${ }^{16}$ Like the Calvinists in the past, or like modernity in general with its West-centric tendencies, the nuns and the bishop are involved in a work of "purification", described by Bruno Latour (1993 [1991]) as the drawing of a "clear line between humans and nonhumans, between the world of agency and that of natural determinism" (Keane 2007: 7). They seem to share the notion that "there is something scandalous or threatening about mixing of humans and things, culture and nature" since it involves moral consequences: "It is this sense of moral danger of mislocated agency that is conveyed by the derogatory accusation of fetishism"17 (ibid.: 23, 54).

To the custodians, another and perhaps more serious cause for concern comes from the fact that the devotees often see no need for clerical mediation in their interactions with religious objects, and frequently get their knowledge on the correct form of such interactions from the alternative specialists such as healers or ekstrasensi. ${ }^{18}$ It is probably this autonomy on the part of the devotees that caused the hostile reaction, triggering restrictions on those practices which take place without clerical leadership, potentially leading the devotees astray.

A number of religious books (including translations from Russian and Greek) have been published on the subject in recent years, some of them available at the Kuklen monastery. These include books such as Ivan Nikolov's Superstition: The Sweet Poison of the Soul (no date); Yeromonah Visarion's Peter Deunov and Vanga: Prophets and Emissaries of the Antichrist (2011) and Superstition Among Today's Christians (2012, co-written with Yeromonah Yoan); Borislav Krachunov's Vanga's True Face (2009) and, in Russian, Igumen N.'s Was Vanga an Orthodox Christian? (2008), as well as Ognyan Khristov's Christianity, Magic and the Ekstrasensi (2011), ${ }^{19}$ which defines (ibid.: 21) the ekstrasensi as people who use incantations instead of praying to God, and do not worship God but rather place themselves in God's place.

Bishop Nikolay is an example of a hierarch who is trying to stamp out this form of esoteric spirituality. On the first Sunday of Lent (March 2, 2015) he actually excommunicated all clairvoyants and ekstrasensi, including people who consult them and use their services (Novinite 2015). The bishop is trying to purge Bulgarian Orthodox Christianity of local 'innovations' in the spirit of Russian Orthodoxy. In practical terms, this translates into a mistrust of any religious practice cultivated in Bulgarian monasteries but not found in Russia, such as the kurbans (animal sacrifices) offered on major holi- 
days, incubation in churches or the healing practices involving chains, as specific to the monastery in Kuklen.

Interestingly, the bishop comes from a family of communist loyalists: according to my respondents and to Internet sources (see Nikolay Plovdivski), the bishop's father was a policeman and an antiterrorism expert in the Bulgarian secret service. Bishop Nikolay was born in Sofia, where he graduated with a master's degree in theology before going on to study at the Moscow Theological Academy, a fact that to some extent may explain his fascination with the Russian model. He was ordained in Vratsa in 1990, and was made a hieromonach by Patriarch Maxim in May 1993. He has since lectured at the Sofia Seminary and became an archimandrite and vicar of the metropolitan bishop of Sofia in the same year. He is remembered for his intentional slight of a papal nuncio: when the nuncio was invited to join a service celebrating the name day of Patriarch Maxim in 2002, Bishop Nikolay had the nuncio's chair removed so that the guest had to stand during the service. As he explained on July 14 on Bulgarian television, his intention was to keep the "heretic" away from the Orthodox altar (Nikolay Plovdivski). He is also a vocal opponent of Bulgaria's integration with the EU.

In 2007, Nikolay became the metropolitan bishop of Plovdiv, and became embroiled in a conflict with the local academic establishment. He made controversial decisions in areas such as conservation of historical monuments (he ordered old frescos at the Metropolitan Church in Plovdiv to be covered with wallpaper), education (in 2013 he founded a Theological Academy in competition with the theology faculty at the University of Plovdiv), and politics (where he holds a pro-Russian line). To Bishop Nikolay, the monastery at Kuklen is the stage for a struggle over the character of Orthodox Christian culture in Bulgaria. On July 1, 2013, the bishop censored Stoyan Atanasov during a sermon preached on the feast of SS Kosmas and Damian after Atanasov asserted in the media that the ayazmo of SS Kosmas and Damian belonged to the local county.

Igumenia Anastasiya is another key representative of this imagery. She was made an igumenia at the Kuklen monastery by Bishop Nikolay, who was her schoolmate. My respondents claim that she comes from the town of Ihtiman, and became a nun late in life. She has an adult son who is a seminary student, and who volunteers for church warden duties when he visits the monastery.

Sister Anastasiya has an imperious, self-assured air. She did an excellent job supervising the renovation project that rescued the monastery from ruin, and she is a successful spiritual leader to candidate nuns; those who fail to fulfil her expectations are quickly dismissed. Two have apparently passed the test, and have now lived in the monastery for several years. Like the igumenia, they tend to keep pilgrim's behaviour under strict control. None of the women has a background in theology, and their policing efforts aimed at ensuring proper ritual observance are often excessive, as when they stop believers engaging in practices permitted in the Sacred Tradition (veneration of relics of saints or the icon of SS Kosmas and Damian). This leads many believers to actually question the igumenia's Christian credentials.

At the same time, the devotees fail to realise the major difference between icons and relics as objects that make the sacred present, as opposed to sources of agency per se, a problem familiar to mediaeval iconophiles. John of Damascus, the first theologian of images, noted that "the image is a likeness that expresses the archetype in such a way that there is always a difference between the two" (Belting 1996: 145). Orthodox Chris- 
tian theology clearly distinguishes between proskynesis (ikonopoklonichestvo, veneration of icons) and latreia (adoration), which should only be given to the Holy Trinity. Treating icons in terms of agency amounts to idolatry and misattribution of divine agency. At the level of praxis, however, proskynesis is not always readily distinguishable from latreia, and veneration from deification. As noted by Sonja Luhrmann (2010: 59), "The icon is necessary to the worshipper because it is an index of the presence of God's grace, but the worshipper is also enjoined to remember constantly that the source of this grace is God, not the image itself".

This complex tension was already worrisome to Byzantine theologians who emphasised, as Brubaker (2012: 109) puts it, that "the image was distinct from its subject and could not be confused with it". Matter was seen as "potentially holy by virtue of the original creation and the connection maintained with God through divine energies" (Hanganu 2010: 44). But it is not holy in itself, it is a medium of God's holiness: "At the same time it has the possibility to fulfil this potentiality by being involved in human activity performed 'in synergy' with God" (ibid.).

The quintessential idea of Orthodox Christianity (which venerates images and treats them as essentially connected to the archetype) can easily turn into its negation (where the archetype is either ignored in favour of the physical object, or else considered to be fully present in the icon). The Palamist doctrine, which emerged in the 14th century, argues that only divine energies are present in icons, in contrast to the divine essence, which remains transcendent and incomprehensible (Palamas 2010: 131).

Believers who realize this distinction are not guilty of idolatry. However, that is not an easy thing to verify: can this distinction be recognised from a believer's posture or gestures? When the custodians engage in efforts to purge and correct the believers' somatic modes of attention, are they not also attacking the deepest foundations of their religious experience? Can chains amount to indices of divine grace in common with icons or relics? To the visiting pilgrims who seek healing, can those objects be merely instances of divine grace manifesting itself in a chosen location, or is the divine grace somehow inherent to the object?

\section{THE MONASTERY'S FOCAL OBJECTS}

\section{The Chains}

As mentioned above, the focal point of the conflict at the Kuklen monastery is a set of chains. Several questions arise: Why do believers seek healing by using the chain? How do they explain and validate the chain's healing powers? What is the opinion of specialists in cultural objectivisation? Do such specialists, or the devotees themselves, perceive this practice as stemming from Orthodox Christian tradition (church exorcisms), or does it have a different origin? And if so, what is that origin? Why did the monastery's former custodians not object to chain-focused rituals, whereas the current ones have made several attempts to remove the chain, a decision that continues to provoke resistance from devotees? How long has the practice been cultivated?

Although accounts from believers and other sources (Shtŭtov 2004; Peev and Marchev 2014: 30) confirm that the chain was once used to hold down sufferers dur- 
ing exorcisms, the question why those chains were used for exorcisms in the first place remains a matter of conjecture. The monastery's records were destroyed in a fire in 1938, so historical sources are scant. We know that there used to be more than one set of chains in the narthex but their number remains unknown. I have heard speculation that there might have been twelve, ten or five sets of chains. Father Ivan and Father S., both of whom used to work in the monastery, claim that there used to be twelve sets, ${ }^{20}$ but this may simply be a narrative device intended to highlight the status of the monastery as a once-famous place of healing.

Some respondents argued that the chains dated back to the Ottoman period. D. believed that the practice to be ancient, arguing that the chains had been placed in the area by the ancients, who were aware of the location's remarkable properties.

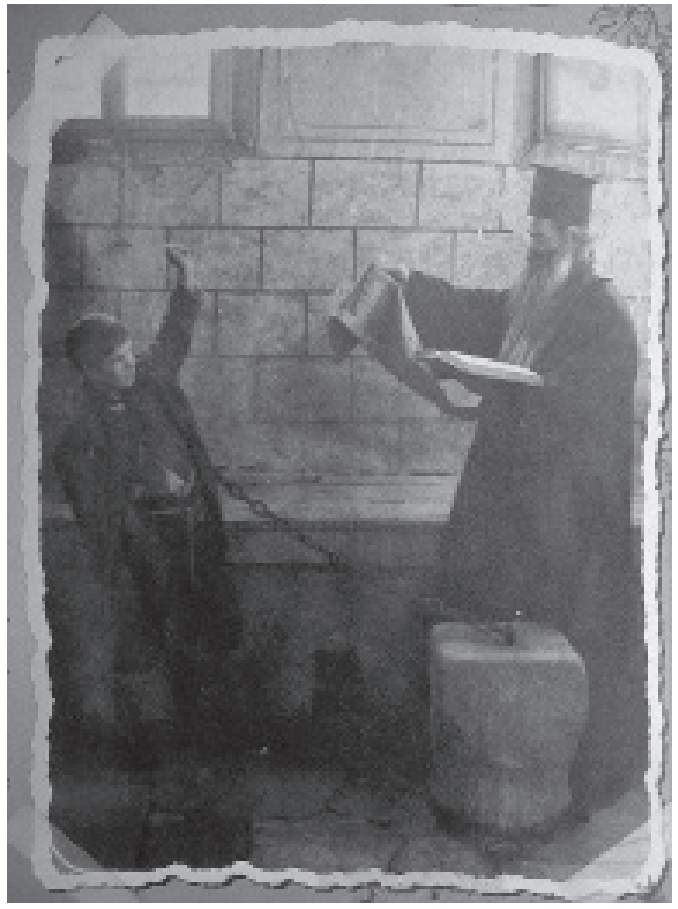

Photo 3. A priest reads a prayer to a boy with a mental disorder in the monastery church of SS Kosmas and Damian, in Kuklen. Photograph from the 1940 s (Peev and Marchev 2014: 30).

According to Father Ivan, the chain at Kuklen is unique in the region. Father E., a priest from Plovdiv, claimed that similar chains could be found in the church of St. Constantine and St. Helen in Plovdiv (I have been unable to check this assertion). Maria Shnitter (2015: 136), a Bulgarian mediaevalist and ethnologist, adds the former monastery of St. Kirik and St. Yulita near Asenovgrad to the list. This suggests that exorcisms involving the use of chains may have once been popular in the region, but the exact age of this tradition cannot be ascertained for lack of sources.

The oldest piece of evidence that I have come across is a photograph of a boy in chains taken during an exorcism in the 1940s. The photograph appears in Part 1 of an album edited by Teodor Peev and Dimitŭr Marchev (2014: 30). ${ }^{21}$ The boy has one arm raised in a defensive gesture, as if to shield himself from the prayer, while a priest is raising his epitrachelion over the boy and reciting a prayer from an open liturgical book (Photo 3). Peev (ibid.) claims that the boy came from Topolovo near Asenovgrad; the exorcism was deemed necessary because he cried a lot after his father went to fight in the war. There is no way of establishing which prayer the priest was reciting, so it is not clear whether the priest considered the boy's condition a case of possession.

The chain is no longer used for exorcism, which is not a popular ritual in Bulgarian churches. When asked about exorcisms, Bulgarian priests tend to change the subject to the Prayer of St Basil, which is used very rarely (if at all). None of my respondents described the people seeking healing at the monastery as suffering from possession instead, they thought they were suffering from mental conditions triggered by illness, 
the evil eye or trauma. Possession was viewed as a thing of the past: they explained that they had not seen any possessed people since the introduction of psychiatric hospitals. ${ }^{22}$

Some respondents argued that the monastery was in fact the earliest psychiatric clinic in the Balkans, ${ }^{23}$ a claim they backed with stories of the special procedures the monks used in the monastery to deal with mentally ill or possessed people; these procedures involved the use of healing water from the ayazmo, which was poured over chainbound sufferers, and prayers recited by members of the clergy. The pilgrims agree that the chains were once used to constrain possessed people, however this does not seem in any way to undermine their healing powers, as evident from testimonies of past healings.

Since the chain is no longer used for exorcisms on possessed or mentally ill people, believers seem to have come up with new meanings and functions. With the waning of belief in demonic possession (which the clergy were not particularly insistent on promoting), ${ }^{24}$ the one remaining chain has taken on a different role. No longer used to constrain sufferers during exorcisms, it has now come to function as a healing object bringing relief to a variety of ailments including pain in the arms or legs, nervous breakdowns or migraines.

Today, pilgrims often learn how to use the chain 'on the fly', taking cues from the more experienced people around them. Handling the chain mainly involves holding it and tracing it up the length of one's leg, from the ankle upwards. The way in which the chain is used depends on the illness in question. One woman ran the chain along her own legs and along the back and neck of her daughter. Another woman ran it along the forehead, nose and legs of her son (preschool age). One man put the chain around his wrist. Another woman had a more comprehensive ritual, running the chain along her legs, then placing it against her hips and lower back, and finally wrapping it around her neck like a dog collar. When interviewed, she explained that the words "in the name of the Father and the Son, and the Holy Spirit. Amen" should be spoken during the practice.

It appears that this self-healing ritual also has a hidden purpose, which is simply to involve the body in the act of recognising the presence of a divine power in the monastery, as involving the body is the most immediate and concrete way of persuading people of the reality of divine power (Csordas 2002: 30). The chain is evidently treated in a way similar to other sacred objects, i.e. as a grace-filled and grace-giving item endowed with special powers. It is difficult to establish what the pilgrims consider to be the source of that power. Accounts of past healings, communicated orally and on online forums, appear to play a significant role, as many people bring their loved ones so they can experience similar healing. By reciting prayers when handling the chain believers establish a synergic relationship with the item similar to that between Orthodox worshippers and holy icons; in a way, they endow these items with a certain potency because only faith can produce healing. At this point one good explanation of the practice seems to be available, namely Collin McDannell's (1995: 19) concept of divine grace as affective presence, which becomes transferred to gestures and material objects. Though far removed from Orthodox theology, this insight appears to reflect closely the feelings of some of the believers.

Those pilgrims who believe in the chain's healing power and agency provide different explanations for its sacred nature. One woman argued that a priest who once 
worked in the monastery described the chain as "life-giving" (zhivotvorni); the woman attributed the healing power of the chain to the use of holy water in rituals involving the use of the chain:

People sprinkled holy water on those chains. And when they did that, he [Father S.] says, that chain has life-giving power [zhivotvorna sila], that's what [the priest] said. And that person [a sufferer visiting the monastery] felt so good thanks to those chains that he insisted that he was feeling no pain when he left. (Kuklen, June $27,2014)$

The liturgical term zhivotvornost or life-giving power, which describes various religious or ecclesiastical vessels or objects in the Orthodox tradition, notably icons, relics and springs, is perfectly attuned to the need for psychosomatic equilibrium as a result of vising a church or shrine. And so, the priest quoted above by my respondent (whom I was able to locate in Kristova Gora), ${ }^{25}$ admitted in a later conversation that the chain had healing power; the priest regarded it as a vehicle or receptacle of divine grace (similar to icons, relics or sacramentalia). He explained that the chain worked by exuding physical warmth/divine grace (blagodat), which he supposed was transmittable through the stone to which the chain was affixed. In practical terms, this grace manifests itself in the fact that diseased body parts redden and become hot following the application of the chain. The chain becomes hot as well:

This chain has this property, it's like an indicator. Say, you place it here, at the back of your neck; if you have a compressed nerve or sciatica the chain immediately starts to warm up, and your skin turns red at that spot. If you put the chain on your head, in the case of people with mental illnesses the chain will get warm. I don't know how that happens exactly, but it does get warmer [...], and you feel a sense of calm. It's divine grace but I couldn't tell you where it comes from, maybe from that stone at the bottom? Maybe it comes from the bottom up, through the stone. (Father S., June 29, 2014)

This demonstrates that the monk shares the imageries of the pilgrims who believe in the healing power of the chains, although he clearly points out that this is a matter of divine power or grace:

I don't know if... but this chain, it simply serves as a conduit, it does not heal, it simply conducts, it's merely a conduit. I am telling you, the chain does not heal, it's simply a carrier. (Female respondent, Kuklen, June 29, 2014)

Not all devotees attribute the chain's healing powers to divine grace. The pilgrims I talked to rarely used that word ${ }^{26}$ mostly preferring to talk about the place's "energy". Even though divine grace and energy are terms which are occasionally used interchangeably in Orthodox theology, devotees tend to use that term in a sense that is more akin to New Age ideology (meaning a kind of cosmic or earthly energy), and not the power of a personal God (Lubańska 2007: 16; Rock 2012-2013: 201; Mikaelsson 2013: 169-170). By way of contrast, Orthodox clergy insist that "the grace believers perceive in holy places and things should not be mistaken with some sort of independent 'prayer energy' which clings to an object or place" (Rock 2012-2013: 201). 
Unlike them, my respondent D. (June 30, 2014), the clairvoyant and former advisor to Father S., argues that the chains are located "at an intersection of the Hartman network":

Parallel diameters circumscribing the whole Earth, those lines are charged with energy, They go east-west and north-south, all around the earth, right? I mean, this spot right here where the chains are is a very potent geopathogenetic zone. They [Bogomil monks] somehow sensed it, and placed the chains there.

According to my respondent, Bogomil ${ }^{27}$ monks did that in the second or third century. This chronological reference is completely ahistorical: the Bogomils were a religious movement active in the Bulgarian territories between the 10th and 15th century. D.'s reference to the Bogomil connection is anthropologically interesting in demonstrating the eclectic nature of her spirituality. In D.'s narrative, figures such as SS Kosmas and Damian, the Bogomils, Peter Deunov, and Baba Vanga all appear to be members of a single camp who, if queried, would corroborate her version of the chain and the Hartman network (para-scientific or pseudoscientific explanations being an inseparable element in this model of faith).

According to D., the chain does not give off positive energy - on the contrary, it soaks up negative energy. She rues the fact that the current igumenia is trying to remove the chain from the church, and reminisces about the "golden age" at the monastery when the custodians heeded her advice on how to use the chain for healing:

She wants to get rid of it. That's what she wants. She wants to get rid of it because she says those are pagan rituals, complete hooey. Well, even if that's the case, so what. To me, scientifically speaking, it's a potent geopathogenetic zone. It's the Hartman network, maybe you've heard. I mean, this is a geopathogenetic zone, meaning it soaks up disease and negative energies from people. I mean, the ancients simply knew where to place them [...] People have been coming here to be healed for a long time, knowing nothing about the Hartman network. I mean, this place simply works. [...] You did the right thing to approach me because I have a lot of veneration for this place, there are many waters in Bulgaria, and holy places where there are harmful zones, to me it's like putting my hands next to a vacuum cleaner. I feel the pull of that energy, and that's how I discover those geopathogenetic zones. This chain, when I place it on my hands, it feels like I'm about to sink into the ground. That's how powerful it is. This is why I keep telling people, God allowing I will be a klisarka here I really love this place, I'm really close to it. (D., Female Deunovian, June 30, 2014)

According to D., the chain should not be removed on account of the unique properties of the place and of the chain itself. At the same time she emphasises that the chain needs to be used properly. There is a fixed amount of time a person should spend sitting on the stone to which the chain is fixed, depending on the type of illness being "drained off". D. practically offers a set of precise operating instructions: for inflammations she recommends sitting for one to three minutes, depending on the person's age and illness. She views illness as "excess energy": the chain first drains off the bad, useless energy so that the sufferer can recover. Once the bad energy has been drained off, however, the chain begins to drain necessary good energy, meaning that excessive use may lead to 
extreme exhaustion, hypotension, loss of consciousness or even death. In this respect, she says, sitting by the chain is like an antibiotic treatment, which can be harmful in wrong doses. As an illustration, D. told me about people who spent too much time sitting on the stone, putting themselves or other people's health in jeopardy. In one story a woman sat on the stone with a six-month-old baby who nearly died after being completely drained of energy. D. (interviewed on June 30, 2014), who was present at the scene, told the woman to get up immediately, and went on to resuscitate the baby: "It drains off the stuff you don't need. That's right, that's why you need to take your time. When you're asleep in that zone, you get that kind of flow. And it drains off the energy you don't need."

In other words, the chains are not endowed with divine grace, but rather act as a carrier of a natural force located in this particular spot for natural reasons related to the location's unique properties. If removed from the Hartman network, the chain would be nearly useless - though not quite, since according to the clairvoyant any metal, regardless of its location, drains energy from humans. Chains, however, do that much more effectively, and they can also carry the unique properties attributed to the Hartman network.

I mean, metals drain energy. For instance, when you get really excited you should grab something made of metal, like a home radiator or any other metal object, to release that electricity. There are other mechanisms as well. I mean, the chain is made of metal, and the place where it's located is made of stone. (D., female Deunovian, June 30, 2014)

In contrast, a former klisarka argued that the chain carried divine grace because it had been blessed. The blessing was as it were coincidental, occurring when holy water was sprinkled over possessed people in chains, however it still managed to endow the chain with unique properties, confirmed by healings. She claimed to have heard it from Father S. who worked at the monastery. She found the igumenia's belief that the chain was a "fetish" absolutely outrageous, and dismissed the igumenia's opinion as being un-Christian. According to D., one might as well treat as idolatrous the crosses some people wear around their necks:

She keeps saying, "The chain is an idol, the chain is an idol". Well, in that case a cross is an idol, if that's the case. It was blessed with holy water, how can it be a fetish? That's just her opinion. (Former klisarka, June 2014)

By way of contrast, the former klisarka treats the chain on a par with a cross: both have been blessed, and are therefore holy. The igumenia's failure to realize this undermines her Christian credentials. Believers find the igumenia's mistrust of physical objects acting as conduits or carriers of divine grace puzzling and confusing.

Father E. (July 4, 2013) from the church of St. Petka in Plovdiv argues that the only chains in the history of Christianity that could be legitimately recognised as sacramentals were the prison chains of St. Peter. ${ }^{28}$ However, there is no connection between the Kuklen chain and St. Peter's chains, not even in the religious imageries of the pilgrims coming to the monastery, and none of my respondents drew this analogy (the only trace of St. Peter's chains that I encountered in my fieldwork was a fresco in the narthex of the new church of St. Petka in Plovdiv depicting the chains). This absence of any founding 
gesture taking place in illo tempore to be recorded either in the Bible or in the apocrypha to furnish some sort of symbolic precedent for healing practices involving chains is perhaps the reason why the Orthodox Church cannot recognise the chain as a religious object. The archetypal Christian healer, Christ never used chains for healing, but rather made gestures of blessing, placing his hands on the sufferer's body, using saliva or (in the apocryphon of King Abgar) impressing his image on a piece of cloth to create an image made without hands, the archetype of the icon. Accordingly, Christianity recognises as legitimate healings produced with the use of icons, relics or other objects that remained in contact with them, and, above all, by the sacrament of anointing the sick (by analogy with Christ, who was anointed before his resurrection). Affording the same status to a chain and to an icon poses a problem: although it is difficult to explain in structural terms why an icon should be effective at producing healings but chains could not, in semiotic terms there is a profound difference between the two.

Importantly, however, the clergy makes no attempt to educate the faithful in this respect. In their declarations, representatives of the church do not see themselves as spiritual leaders, nor do they seek to establish a rapport with the faithful. Instead, they seek to manage pilgrim behaviour by gradually changing the sacred space and the rules regulating the use of its resources. ${ }^{29}$ In this way the believers' bodies are effectively disciplined in a non-discursive manner by depriving the pilgrims of the space required to express favoured somatic modes of attention. It is not unreasonable to suppose that the single remaining chain may at one point be removed as well, a surmise shared by the devotees.

Based on information available online and on my conversations with the former klisarka I established that the nuns had made several attempts to remove the chain from the narthex. In 2012, a little table with liturgical coverings was placed over the chain, barring access to the object. This provoked outrage, as a group of people arrived on the scene with a hidden camera to force the igumenia to remove the table, and the confrontation escalated to threats of physical violence.

K.: The people of Kuklen hate her already. They're no longer willing to help. They used to come and help, I used to come and help for four years, but I don't anymore. I said, to me you're not a Christian, I won't be coming to help. This winter she came to me again [to ask for help], and I said, "I don't want to help, I'm 80 years old. I can't work. I just won't." There's nothing you can do to help that kind of person. M.L: So, it was you who told her about the chains, and she removed the table?

K.: No, that was the people, they had an argument with her. One man came up, grabbed the table and threw it in front of her, saying: "I'm going to show you the back of my hand, I will crush you! Leave the chains alone!" And she backed down. That was two years ago [in 2012]. (K., Former klisarka, Kuklen, in June 2014)

When I visited the monastery again in 2014, rumours were circulating that the chain had been removed. People intervened again, and the chain was replaced right before the feast of SS Kosmas and Damian. However, a photograph of the bench taken a few years previously and published in Yana Gergova's book (2015: 267-268) along with her account of the believers' behaviour suggests that the nuns had already made efforts to interfere with the setting to influence the pilgrims' somatic practices; they removed the little bench fastened over the stone to which the chain is fixed, formerly an integral part 
used by pilgrims. ${ }^{30}$ In 2013, pilgrims willing to use the chain had to sit directly on the stone, which hindered the practice.

Some constraints have also been imposed on the people working in the monastery in terms of public expressions of opinions or beliefs. On the igumenia's orders I was prevented from interviewing the nuns working in the monastery or the shop assistant in the monastery bookshop. I was unable to interview the priest working at the monastery. The igumenia agreed to an interview, but declined to be recorded. The igumenia and the monastery's chaplain appeared to be afraid to do anything that might meet with disapproval from Bishop Nikolay.

The faithful are unwilling to defer to the bishop, possibly because not many people take Holy Communion or go to confession, so most have no sense of spiritual dependence on the clergy. The impression of the faithful is that the quality of their religious life is tangibly deteriorating. In conversations and in Internet forums they voice dissatisfaction with the church hierarchy trying to keep them away from the monastery. A local complained on the Nova Televiziya channel. Excerpts of the interview later appeared in an online newspaper (Blitz 2013), which was commented by an inhabitant of Kuklen:

With Sister Anastasiya and Bishop Nikolay at the helm, they've simply struck out the monastery and that's that. No one's allowed to visit. People are forbidden to kiss the icons. They've taken the chains away, though they have great healing powers, and healed many people. We, the people of Kuklen, are being cordoned off. We're not allowed to enter. We're not allowed to sleep there [in the church].

The topic of the chains came up as well, with inhabitants of Kuklen accusing the igumenia of denying their healing powers because of the metropolitan bishop's influence: "We collected signatures asking for her to be moved somewhere else. But she is a schoolmate of Nikolay, so that was never going to work." (Female Deunovian, June 30, 2014)

Some took to Internet forums to criticize their bishop online (see Blitz 2013): "When he gives up his Mercedes cars and his Rolex watches I will come to believe that he is a clergyman filled with God's grace. God forbid he should be an intermediary between me and God!"

Importantly, the devotee expressed the need to experience divine grace, but also believed that the bishop was not suited to be his/her representative. The believers want to make their own decisions about the location of that grace and healing power, mainly relying on vernacular tradition and individual somatic sensibility as they objectivise religious experience and ignore the opinions of the clergy. Confirmed by accounts of past miracles, the chain's efficacy means that pilgrims view it as a vehicle of grace. The monastery's custodians are generally regarded as imposing constraints on people's ability to access the objects. The problem is not limited to the chain alone; the custodians have also objected to a miro-dripping icon (miro meaning chrism or anointing oil), or to relics, and occasionally to a believer's somatic mode of attention during prayer.

\section{Other Controversial Healing Objects}

The problem appears to affect other aspects of somatic modes of attention. Negative experiences with the chain seem to have increased the vigilance of Igumenia Anastasiya 
and of other nuns working in the monastery, who view the religious practices of the faithful in the monastery as more examples of heretical imagery and try to make sure that their prayers and modes of veneration of icons and relics adhere to the Orthodox way.

As a result, the igumenia is wary of even seemingly innocuous gestures such as closing one's eyes in prayer. A respondent claimed to have seen the igumenia reprimanding a woman who was praying with her eyes closed. I had a similar experience when I asked a nun for permission to photograph a stone plaque situated in the narthex, containing a carving of the sun and inscriptions in old Greek. The nun declined, and forbade me to copy the plaque into my notebook by hand, arguing that I might produce a distorted image of the plaque. She made me feel unworthy of coming into the possession of that image in any way, even though the image was simply two suns facing each other, captioned with a Greek inscription. The plaque was not a conventional church decoration or an object of Orthodox cult. Paradoxically, the nun who forbade me to copy the design effectively treated the plaque as a holy object, engaging in the same kind of behaviour that she criticised in the faithful who treated the chains as sacred. On the other hand, perhaps the nun's refusal was a simple reflex gesture. Generally wary of the problematic miracular (and potentially idolatrous) sensitivity of the pilgrims, who tend to regard all church objects as capable of working miracles, she may have suspected me of harbouring similarly idolatrous tendencies, and simply wanted to turn my attention away. Respondents reported similar experiences. A woman complained that the faithful were no longer permitted to touch or kiss the relic of SS Kosmas and Damian (a hand kept in the monastery), even though it used to be possible to ask the monks in the monastery for a vodosvet (blessing of the water) involving the relic, which would have been placed in such a way as to practically encourage veneration. The theft of a fragment of the reliquary might have been responsible for those constraints, but the decision also seems to have been influenced by excessive veneration, as evidenced in the following comment:

K.: There used to be a little table at St. Vrachs' where they kept a hand of St Kosmas, people would come to touch and kiss it. Then they stole the silver, and it [the hand] was placed inside a kind of box, so now you can only place your hand on top of the glass at the top. That's the only way to take in the energy that's being produced. The hand used to be encased in silver, and was always displayed on the table so people could kiss it.

M.L.: When was that?

K.: When I was 28. Now I'm 80. A very long time ago.

M.L.: And the hand was once accessible to the people?

K.: Yes, but then there was all this rotation, the nuns, the monks, and somebody took the silver.

M.L.: They stole the silver?

K.: Yes, and the hand was left, with three bones, three bones. That's right, that's all there is. But they keep it in there.

M.L.: And you can't touch it?

K.: No, no, you can't touch it. It's wrapped in cotton wool (pamuk), and kept inside a box in the big church. It used to be encased in silver, and it was available to everybody. I used to come to help out for four hours at the monastery, but now that 
those women are here, the nuns, they simply don't let us touch the hand, they wrapped it in there. (K., former klisarka, June 27, 2014)

Presumably, the various steps taken to prevent the faithful from accessing icons or relics are part of Igumenia Anastasiya's repercussions against practices connected with the church chain. In an attempt to dissuade pilgrims from what she believes is a somewhat 'fetishistic' attitude to such objects, the igumenia takes her efforts to excess, effectively hindering pilgrim interactions with cult objects that ought to be venerated according to the Orthodox Christian canon, and paradoxically treats Orthodox relics as idols. In official Orthodox tradition, blessed icons and relics are vehicles of divine grace, and physical contact with such objects, expressed through proskynesis (kissing and bowing) is an inalienable element of Orthodox cult.

Not many believers participate in the whole service, but all of those who come into the church perform the gestures of proskynesis. Nonetheless, the nun appears to regard aniconicity and mistrust of physical objects as being closer to Orthodox Christianity than the synesthetic contact of the faithful with objects viewed as miraculous, be it chains, icons or relics. The igumenia's initiatives aimed at disciplining the pilgrims' somatic modes of attention are intended to eliminate idolatrous tendencies, and to teach believers to communicate with God without the mediation of tangible objects. In her opinion, a visit to the monastery should be motivated by intentions of prayer and faith in SS Kosmas and Damian rather than by a cult of physical objects, since excessive attention to physical objects in matters of cult is essentially idolatrous. ${ }^{31}$ Her attitude to healing objects could thus be described as almost iconoclastic, or at least deeply suspicious, itself an attitude verging on heresy by the lights of Orthodox doctrine.

Another object kept away from the faithful is the miracle-working icon of SS Kosmas and Damian, believed to be effective in curing headaches. Father S., a former monastery custodian, told me during our conversation at Kristova Gora on June 29, 2014 that the icon had been fenced off:

Fr.S.: I mean, headaches are cured in front of the icon of SS Kosmas and Damian, inside, to the right. Now it's fenced off, they're saying you can't be cured.

M.L.: Over there, by the chain?

Fr.S.: No, inside the church. You get Lord Jesus on the right hand side, and then Kosmas and Damian [describing the layout of the iconostasis]. There used to be this kind of little horn in between them. When you placed your head against that horn, I mean your forehead, your headache was gone immediately.

M.L.: You mean, in the icon, right?

Fr.S.: Yes, in the icon, but they no longer allow that. Now the place is fenced off, no entry.

Apparently, even an icon (whose cult is validated during the Feast of Orthodoxy) can be treated as an idol when a protrusion on the icon is believed to have healing properties, in which case the only way to control this physical mode of spirituality is to hide the object from believers. However, some believers interpret this as a departure from the Orthodox tradition:

K.: She actually put like a sill by the icons, so you couldn't kiss them. Our people went there, people from our quarter, and they had a row with her. "Get that sill 
removed! You can't have people not kissing [the icon]!" And she goes, "People were getting ill, they were catching infections!"

M.L.: It's Orthodox, to kiss icons.

K.: I mean, she didn't want anyone to kiss the icons. Even though Jesus Christ once... I don't know if you've read the Bible, he wiped his face, and they took that cloth bearing an image of his face.

M.L.: An icon made without hands.

K.: Yes, they took that to the tsar, he washed, he was in a really bad state, but he had a drink of the water in which the cloth had been dipped, and he recovered, that's how they started drawing the face of Jesus to be kissed. But she [the igumenia], like I said, she's not Christian. Jesus Christ once drove out such disbelievers when they weren't admitting people. When your belief starts to wane, you end up an unbeliever. Just look at the things she's doing, that woman has no fear of God. (K., former klisarka, June 2014)

This comment demonstrates my respondent's familiarity with the history of the cult of icons. The apocryphal story of King Abgar's miraculous recovery thanks to an icon "made without hands" (nerukotvorna) played a key role in the iconoclastic controversy, serving as evidence that Christ himself validated the cult of icons by miraculously creating his own likeness, copies of which circulated in Christian communities. However, despite the victory of the iconophiles, celebrated by the Feast of the Triumph of Orthodoxy, the cult of holy objects such as icons and relics continues to pose practical problems to the religious elites as the Orthodox nuns at the Kuklen monastery believe that any object perceived to be endowed with inherent agency (as opposed to transcendent agency where God's divine grace and spiritual powers are manifested) should not be venerated (cf. Engelke 2012: 42). ${ }^{32}$

\section{CONCLUSIONS}

The conflict at the Kuklen monastery as presented in this article illustrates the fact that interpreting the intentions behind the gestures of believers is a much harder task for the priests and nuns in real life than it would appear from theological works for the elites. This is especially the case since the normative descriptions of proskynesis contained in the latter are difficult to live up to. In their policing efforts, the nuns are not motivated by theological considerations (with which they are unfamiliar), and the igumenia actually does not consider theology useful or valuable. To them, the difference between Orthodox versus idolatrous cult is an intuitive judgement call. The policy of modifying the setting in the monastery by removing, obscuring or fencing off problematic elements (the icon of SS Kosmas and Damian, the relics of the saints, the chain) is motivated by a fear that the monastery might come to be primarily associated with those objects rather than with the saints themselves. By fearing that the monastery might become a place where idolatry is propagated, they promote instead what is almost a kind of iconoclasm, for instance by hiding or obscuring some of the icons.

This fear leads to excessive attempts to discipline the believers' somatic modes of attention, leaving them with no alternative capable of meeting their miracular needs. The custodians' anti-syncretic attitudes and their refusal to engage in dialogue causes 
deepening frustration among the pilgrims, who insist on being granted access to objects which they regard with an equal fascination, whether those are icons or relics or a set of chains. To chain-focused pilgrims, the sacred (or healing) energies, can be made present by any physical object. The current custodians of the monastery regard this approach as a scandalous subjectivisation of physical matter, which has the potential to oust God, the only proper addressee of prayers for healing, who cannot be contained by matter and must remain transcendent. The two sides view each other as interlopers who fail to realize the monastery's unique character and usurp its space. It appears that the syncretic approach of the monks formerly acting as custodians was more compatible with the pilgrims' imageries; closer to the vernacular, embodied religious life, it left more room for somatic expression as the clergy and the faithful were a single community. Now the two parties are locked in a conflict over dominance, the chain serves as a litmus test showing which party has the upper hand at any given time.

Watching this process one might conclude that the iconoclastic controversy is far from over, and Bulgaria's Orthodox Christian religious culture is in some places belatedly undergoing a local process of "purification". At Kuklen, this process occasionally takes on a paradoxical form which undermines the foundations of Orthodoxy, in that denying the agency of icons and relics goes against the heart of the Orthodox tradition. At this point it is difficult to foresee which imagery will prevail to become associated with the monastery. At present, the embodied religious imagery of the pilgrims is primarily shaped by the elderly women (religious leaders). So far, efforts at religious socialisation launched by the bishop and the nuns appears to have failed. Indeed, the two groups seem to be isolated from, and antagonistic towards, each other.

NOTES

1 All quotations of the interviews are translated from Bulgarian.

2 The monastery of SS Kosmas and Damian, two physicians famed for healing powers also known as SS Vrachs (sveti Vrachove), is among the most popular in Bulgaria. On the feast of the patron saints, pilgrims from the area come to wash their bodies with water from a healing spring (ayazmo) dedicated to the saints, located some 300 yards from the monastery wall, worship at their relics and miracle-working icon, and seek healing using the chain.

3 Deunovians are followers of the occult teachings of Peter Deunov (1864-1944), founder of the Bulgarian White Brotherhood, see Note 6.

4 Comparative field research conducted in Ukraine by my collaborator, Magdalena Zatorska, suggests that a similar conflict is playing out in that country, where the official Church likewise is opposed to esoteric spirituality.

5 Analogous processes are taking place in Muslim communities in the Rhodopes, where young Muslim religious leaders often regard as 'true' a variant of Islam practiced in Saudi Arabia, as opposed to the post-Ottoman form of Islam practised in Bulgaria (Lubanska 2015).

6 Vangeliya Pandeva Dimitrova, a Bulgarian clairvoyant influential with Bulgaria's communist oligarchs.

7 Peter Deunov was an occultist and mystic from north-western Bulgaria who attended the American Seminary School in Svishtov and was further educated in America, where he studied theology at the Boston University before joining Rosicrucian circles and reading widely in American and Russian esoteric literature (cf. Szwat-Gyłybowa 2011: 89). Back in Bulgaria in 1896, Deunov published a new interpretation of the Bible propagating neo-gnosis and Slavic mission- 
ism. His missionary activity in Bulgaria involved establishing the Association for the Propagation of the Religious Spirit in the Bulgarian Nation, renamed The White Brotherhood in 1918. Members attended annual conventions and listened to Deunov's sermons, recordings of which remain largely untranscribed. Deunov was close to the circles of power in Bulgaria. He died in 1944, the year Bulgaria became a communist regime. Deunov's school was closed down, and his disciples faced repressions. The Brotherhood was revived after the fall of the communist regime in 1989 (Krasztev and Kerenyi 2001: 80; Szwat-Gyłybowa 2011: 90-91). Today it has many sympathizers in Bulgaria, rivalling the Bulgarian Orthodox Church. Deunov is considered a heretic by the Orthodox Church, which excommunicated him in 1916 (Toncheva 2015: 214). In 2012, Deunov was "voted into second place by the Bulgarian public during a national poll to find the 'Greatest Bulgarians' [...], provoking the Bulgarian Orthodox Church to declare him an antichrist" (ibid.:14).

8 Arguably, the thing that appears to trouble some members of the clergy is what Matthew Engelke (2007: 9) terms "the problem of presence": "Simply put, the problem of presence is how a religious subject defines and claims to construct a relationship with the divine through the investment of authority and meaning in certain words, actions, and objects".

9 Singular: an extrasens. A term derived from extra-sensory perception. It is used to refer to people who have paranormal healing abilities and strong inner energy (Rock 2012-2013: 201).

10 I only use initials to protect the anonymity of my respondents. Father Ivan Shtŭtov is an exception because he is a published author of a book on the monastery.

11 A female helper in a church.

12 More on this subject below.

13 I refer here to a type of religious life self-reported as Orthodox Christian, which in practice is a conglomerate of beliefs and practices of pre-Christian, Byzantine and Ottoman provenance, processed and reworked over the centuries in accordance with the local modus viviendi. Key elements include the cult of saints and material religious practices aimed at achieving individual and communal health and wellbeing. Crucially, this involves a relationship of reciprocity with saints who receive sacrifices (kurbans) from believers (Lubanska 2015: 107). Since the 20th century this form of religiosity has been increasingly coloured by new religious movements, which at present is felt more in the cities than in the Bulgarian provinces.

14 Vihra Baeva (2012: 170) believes that they are still a dynamic group offering a religious alternative to the priests, and often capable of introducing their recognized traditions into church life. I propose a different nomenclature for such juxtaposed models of religious life since Baeva's "grannies" draw on new religious movements far more than would appear at first sight, and the priests are a divided group, not all of whom are opposed to the "grannies". Some of the priests clearly share the popular religious imageries, others keep their distance and attempt to modify them "in the spirit of Orthodox Christianity", very much an open-ended designation.

$15 \mathrm{I}$ find it interesting that "concepts such as agency are rarely made explicit, but rather are presupposed by the ways people act and evaluate the actions of others" (Keane 2007: 59).

16 I refer here to icons and relicts, which in official Orthodox theology are perceived as places where divine grace is made present.

17 Keane (2007: 67) is writing about Protestant missionaries, however the attitude of the bishop and the nuns towards physical objects as vehicles of agency is surprisingly similar to the Calvinism's semiotic ideology, which "sharpened the distinction between material expression and immaterial meaning and put them in a hierarchical relations to one another, endowing the distinction with grave moral consequences. It privileged belief, associated with immaterial meaning, over practices that threatened to subordinate belief to material form."

18 Sonja Luhrmann (2010: 70) made similar observations concerning the religious cult in the autonomous republic of Marij El in the Volga region of Russia.

19 Here I have provided the English translations of titles to make the content clearer. 
20 Yana Gergova (2015: 264), another researcher working on the ritual practices in that monastery, mentions the same figure.

21 I am grateful to Petko Georgiev, archivist at the National Library in Plovdiv, for helping me locate this source.

22 The situation is different in the Western churches where exorcisms are increasingly a routine, daily practice, especially in the Pentecostal denominations. Following the Second Vatican Council the Pentecostal influence is increasingly present in Catholicism in charismatic religious movements (see for instance Csordas 2002).

23 I found this claim in a guidebook to the churches of Plovdiv, but it is not corroborated by historical sources (Doichinov 2005: 111).

24 This stands in contrast to Ukraine, where exorcisms are still practised and relatively popular. In Ukraine, exorcisms are accompanied by somatic reactions similar to those described by Csordas (2002) among the Western Christian charismatic communities (see Naumescu 2010: 165).

25 The priest was moved from the Kuklen monastery to Kristova Gora.

26 In this context we should mention the practices of pilgrims in Russia recently studied by Stella Rock, who recorded the frequent use of the word grace (blagodat) in the discourse of the pilgrims, and identified the willingness to experience grace as one of the main motivations. Similarly, Rock notes the discrepancies between the definition of grace between the Church and the pilgrims (Rock 2012-2013: 195).

27 The Bogomils were a neo-Manichaean sect named after their founder. Their doctrine was probably influenced by the Massalians and the Paulicians. They were opposed to the Orthodox Church, had a dualistic interpretation of the New Testament, and practised prayer leading to mystical ecstasy, which they considered proof of spiritual perfection and liberation from one's inner demon, making one incapable of sinning. (cf. Szwat-Gyłybowa 2011: 40)

28 Probably for that reason Gergova (2015: 270) compares the chain in the Kuklen monastery to the chains of St. Peter held in the church of San Pietro in Vincoli in Rome.

29 Stella Rock noted analogous practices at Diveevo (private e-mail correspondence, May 1, 2013).

30 The bench is also visible in one of the photographs posted on a website devoted to the monastery (see Minovski 2007).

31 The nun does not use the term idolatry, simply referring to a cult of idols.

32 Engelke (2012: 42) writes of a similarly reserved attitude to matter in the Apostolic Church Jowane Masowe Chishanu in Zimbabwe, whose devotees try to foster "live and direct faith" understood as submission to the direct and healing influence of the Holy Spirit, and even reject the Bible as an unnecessary form of mediation of faith (associated with White colonisation and therefore suspect). Even if they use objects in their practices, they treat them as venues for the manifestations of the spiritual powers of the Holy Spirit, attributing no substantive powers to the objects themselves. One exception (to some extent) is honey used for its medicinal properties, which some members believe to possess inherent healing properties, but other than that they generally reject "the potential of religious representation through objects" (ibid.: 50), and want their faith to have an immaterial quality.

\section{REFERENCES}

Baeva, Vihra. 2012. Nishkata na zhivota. Mezhdu kolancheto za rozhba i bogorodichniya poyas. Sofia: Prof. Marin Drinov Publishing Нouse. [Баева, Вихра. 2012. Нишката на живота. Между коланчето за рожба и богородичния пояс. София: АИ Проф. Марин Дринов.]

Belting, Hans. 1996. Likeness and Presence. Chicago, IL: University of Chicago Press.

Blit. 2013. Selo na nozh s mitropolit Nikolay zaradi lechebni verigi, izvor i moshchi. http:// 
www.blitz.bg/news/article/208333 (accessed March 25, 2014). [Блиц. 2013. Село на нож с митроподит Николай заради лечебни вериги, извор и мощи. http://www.blitz.bg/news/ article/208333]

Bourdieu, Pierre. 1977. Outline a Theory of Practice. Cambridge: Cambridge University Press.

Brubaker, Leslie. 2012. Inventing Byzantine Iconoclasm. London: Bristol Classic Press.

Khristov, Ognyan. 2011. Khristiyanstvo sreshtu magiite i ekstrasensite. Sofia: Enoriyski izdatelski tsentŭr "Sts. Tsiril i Metodiy". [Христов, Огнян. 2011. Християнство срещу магиите и екстрасенсите. София: Енорийски издателски центьр “Сц. Цирил и Методий”.]

Ciesielska, Ida. 2015. Kompleks Wanga w Rupite jako sanktuarium religijne. Unpublished typescript.

Csordas, Thomas. 1994. The Sacred Self. A Cultural Phenomenology of Charismatic Healing. Berkeley, CA; Los Angeles, CA: University of California Press.

Csordas, Thomas. 2002. Body/Meaning/Healing. New York, NY: Palgrave.

Doychinov, Doichin. 2005. Plovdivski svetlini. Plovdiv: Compass P-Plovdiv. [Дойчинов, Доичин. 2005. Пловдивски светлини. Пловдив: Compass P-Plovdiv.]

Eade, John and Michael Sallnow. 1991. Introduction. - Contesting the Sacred. The Anthropology of Christian Pilgrimage, edited by John Eade and Michael J. Sallnow. Urbana, IL; Chicago, IL: University of Illinois Press, 1-29.

Engelke, Matthew. 2007. A Problem of Presence. Beyond Scripture in an African Church. Berkeley, CA, New York, NY; London: University of California Press.

Engelke, Matthew. 2012. Dangerous Things. One African Genealogy. - Things. Religion and Question of Materiality, edited by Dick Houtman and Birgit Meyer. New York, NY: Fordham University Press, 40-61.

Evdokimov, Paul. 1964. Prawostawie. Warsawa: Pax.

Georgieva, Albena. 2012. Folklorni izmereniya na khristiyanstvoto. Sofia: Prosveta. [Георгиева, Албена. 2012. Фолклорни измерения на християнството. София: Просвета.]

Gergova, Yana. 2015. Kultŭt kŭm bezsrebŭrnitsi v Bŭlgariya. Obrazi, vyarvaniya i ritualni praktiki. Sofia: Gutenberg. [Гергова, Яна. 2015. Култът към безсребърници в България. Образи, вярвания и ритуални практики. София: Гутенберг.]

Ghodsee, Kristen. 2009. Symphonic Secularism: Eastern Orthodoxy, Ethnic Identity and Religious Freedoms in Contemporary Bulgaria. - Anthropology of East Europe Review 27 (2): 227-252.

Hanganu, Gabriele. 2010. Eastern Christians and Religious Objects: Personal and Material Biographies Entangled. - Eastern Christians in Anthropological Perspective, edited by Chris Hann and Hermann Goltz. Berkeley, CA; Los Angeles, CA: University of California Press, 33-56.

Igumen N. 2008. Byla li Vanga pravoslavnoy khristiankoy. Moskva: Danilov m-r. [Игумен N. 2008. Была ли Ванга православной христианкой. Москва: Данилов м-р.]

Keane, Webb. 2007. Christian Moderns. Freedom and Fetish in the Mission Encounter. Berkeley, CA; Los Angeles, CA; London: University of California Press.

Kormina, Jeanne. 2010. Avtobusniki: Russian Orthodox Pilgrims' Longing for Authenticity. Eastern Christians in Anthropological Perspective, edited by Chris Hann and Hermann Goltz. Berkeley, CA; Los Angeles, CA: University of California Press, 267-288.

Krachunov, Borislav. 2009. Istinsko litse na Vanga. Sofia: Vechen zhivot. [Крачунов, Борислав. 2009. Истинско лице на Ванга. Софиа: Вечен живот].

Krasztev, Péter and Sabina Kerenyi. 2001. Spirit Awakening at Sunrise. Petar Danov and the White Brotherhood: Attempting Interpretation. - Ethnologia Balkanica 5: 79-100.

Latour, Bruno. 1993 [1991]. We Have Never Been Modern. Harvard: Harvard University Press.

Lindquist, Galina. 2006. Conjuring Hope. Magic and Healing in Contemporary Russia. New York, NY; Oxford: Berghahn Books.

Lubańska, Magdalena. 2007. Problemy etnograficznych badań nad religijnością. - Religijność chrześcijan obrządku wschodniego na pograniczu polsko-ukrainskim, edited by Magdalena Lubańska. Warsaw: DiG, IEiAK UW, 7-32.

Lubanska: Healing Chains, Relationships of Power and Competing Religious Imageries in the Monastery of 
Lubanska, Magdalena. 2015. Muslims and Christians in the Bulgarian Rhodopes. Studies on Religious (Anti)syncretism. Warsaw, Berlin: De Gruyter Open. http://www.degruyter.com/view/product/458709 (accessed June 2, 2016).

Luhrmann, Sonya. 2010. A Dual Quarell of Images on the Middle Volga: Icon Veneration in the Face of Protestant and Pagan Critique. - Eastern Christians in Anthropological Perspective, edited by Chris Hann and Hermann Goltz. Berkeley, CA; Los Angeles, CA: University of California Press, 56-78.

Marinov, Dimitŭr. 1994. Narodna vyara i religiozni obichai. Sofia: BAN. [Маринов, Димитър. 1994. Народна вяра и религиозни обичаи. Софиа: БАН.]

McDanell, Conell. 1995. Piety, Art, Fashion: The Religious Object. - Material Christianity. Religion and Popular Culture in America. New Heaven, CT; London: Yale University Press, 17-66.

Merleau-Ponty, Maurice. 1996 [1945]. Phenomenology of Perception. Translated by Colin Smith. Delhi: Motilal Barnasidas Publishers.

Mikaelsson, Lisbeth. 2013. New Age and the Spirit of Capitalism: Energy as Cognitive Currency. - New Age Spirituality. Rethinking Religion, edited by Steven J. Sutcliffe and Ingvild. S. Gilhus. Durham: Acumen, 160-173.

Minovski, Valentin. 2007. Kuklenski manastir "Sv. Kozma i Damyan". http://dveri.bg/dfu (accessed November 16, 2015). [Миновски, Валентин. 2007. Кукленски манастир “Св. Козма и Дамян". http://dveri.bg/dfu]

Morgan, David. 2010. Introduction: The Matter of Belief. - Religion and Material Culture. The Matter of Belief, edited by David Morgan. London; New York, NY: Routledge, 1-18.

Naumescu, Vlad. 2010. Exorcising Demons in Post-Soviet Ukraine: A Monastic Community and Imagistic Practise. - Eastern Christians in Anthropological Perspective, edited by Chris Hann and Hann Goltz. Berkeley, CA; Los Angeles, CA: University of California Press, 155-176.

Nikolay Plovdivski. - Wikipedia. https://bg.wikipedia.org/wiki/Николай_Пловдивски (accessed December 1, 2015). [Николай Пловдивски. - Уикипедия. https://bg.wikipedia.org/wiki/ Николай_Пловдивски]

Nikolov, Ivan. Sueveriyata-tazi sladka otrova na dushata! Vitezda. [Николов, Иван. Суевериятатази сладка отрова на душата! Витезда.]

Novinite. 2015. Anatema za vrachki ekstrasensi i ikumenitsi. http://novinite.bg/articles/88873/ Anatema-za-vrachki-ekstrasensi-i-ikumenici (accessed December 1, 2015). [Novinite. 2015. Анатема за врачки, екстрасенси и икуменици. http://novinite.bg/articles/88873/Anatemaza-vrachki-ekstrasensi-i-ikumenici]

Palamas, Gregory. 2010. Obrona szczegółowa. - Palamas, Bułgakow, Łosiew. Rożważania o religii, imieniu Bożym, tragedii i filozofii, wojnie i prawach człowieka, edited by Lilianna Kiejzik. WarSzawa: Scholar, 129-163.

Panchenko, Aleksander. 2011. Morality, Utopia, Discipline. New Religious Movements and Soviet Culture. - Multiple Moralities and Religions in Post-Soviet Russia, edited by Jarrett Zigon. New York, NY: Berghahn Books, 119-145.

Panchenko, Aleksander. 2012. 'Popular Orthodoxy' and Identity in Soviet and Post-Soviet Russia. - Soviet and Post-Soviet Identities, edited by Mark Bassin and Catriona Kelly. Cambridge: Cambridge University Press, 321-340.

Peev, Teodor and Dimitŭr Marchev. 2014. Stari fotografii ot Stanimaka i Stanimashko. Album 1. Asenovgrad. [Пеев, Теодор и Димитьр Марчев. 2014. Стари фотографии от Станимака и Станимашко. Албум 1. Асеновград.]

Rock, Stella. 2007. Introduction. - Popular Religion in Russia. 'Double belief' and Making of an Academic Myth. New York, NY: Routledge, 1-15.

Rock, Stella. 2012-2013. Seeking out the Sacred. Grace and Place in Contemporary Russian Pilgrimage. - Modern Greek Studies Yearbook 28-29: 192-218. 
Shnitter, Maria. 2015. Choveshkoto tyalo v konteksta na pravoslavniya ritual. Aspekti na vsekidneven zhivot na bŭlgarite v predmoderna epokha. Postdoctoral dissertation. University of Plovdiv. [Шнитер, Мария. 2015. Човешкото тяло в контекста на православния ритуал. Аспекти на всекидневен живот на бъдгарите в премодерна епоха. Дисертационен труд. Пловдивски университет.]

Shtŭtov, Ivan. 2004. Kuklenski manastir. Sofia: Bŭlgarska Knizhnitsa. [Щьтов, Иван. 2004. Кукленски манастир. София: Българска Книжница.]

Szwat-Gyłybowa, Grażyna. 2006. Projekt desekularyzacji kultury bułgarskiej w czasach Żiwkowowskich? - Slavica leguntur. Aktualne problemy badawcze slawistyki, edited by Joanna Królak and Jerzy Molas. Warszawa: Instytut Slawistyki Zachodniej i Południowej, 333-341.

Szwat-Gyłybowa, Grażyna. 2011. Entries: bogomiłowie, Dynow Petyr. - Leksykon tradycji bułgarskiej. Warszawa: SOWA, 89-91.

Talbot, Alice-Mary. 2002. Pilgrimage to Healing Shrines. The Evidence of Miracle Accounts. Dumbarton Oak Papers 56, edited by Alice-Mary Talbot. Washington, DC: Dumbarton Oaks, 153-173.

Taylor, Charles. 2007. The Bulwarks of Belief. - A Secular Age. Cambridge, MA; London: Harvard University Press, 25-89.

Toncheva, Svetoslava. 2015. Out of the New Spirituality of the Twentieth Century. The Dawn of Anthroposophy, the White Brotherhood and the Unified Teaching. Berlin: Frank \& Timme Gmbh Verlag.

Valtchinova, Galia. 2007. From Postsocialist Religious Revival to a Socialist Seer and Vice Versa: The Remaking of Religion in Postsocialit Bulgaria. Max Planck Institute for Social Anthropol-

ogy Working Papers 98. Halle, Saale: Max Planck Institute for Social Anthropology.

Visarion Zografski, Yeromonah. 2011. Petŭr Danov i Vanga prorotsi i predtechi na antikhrista. Atos: Sv. Vmch Georgi Zograf. [Висарион Зографски, Иеромонах. 2011. Петьр Дьнов и Ванга пророци и предтечи на антихриста. Атос: Св. Вмч Георги Зограф.]

Visarion Zografski, Yeromonah and Yeromonah Yoan. 2012. Sueveriya sred dneshtnite khristyani. Atos: Sv. Vmch Georgi Zograf. [Висарион Зографски, Йеромонах і Йеромонах Йоан. 2012. Суеверия сред днещните христяни. Атос: Св. Вмч Георги Зограф.] 